\title{
A survey for Toxoplasma gondii in red fox (Vulpes vulpes) from Finnmark County, Norway
}

Renate Sjølie Andresen

From Parasite infections of domestic animals in the Nordic countries - emerging threats and challenges.

The 22nd Symposium of the Nordic Committee for Veterinary Scientific Cooperation (NKVet)

Helsinki, Finland. 7-9 September 2008

\section{Summary}

Samples (blood or tissue fluid) from 405 red foxes (Vulpes vulpes) from Finnmark, Northern Norway, were assayed for antibodies against $T$. gondii using the direct agglutination test (DAT). The proportion of seropositive animals was $42.5 \%$, with no significant relationship between sex and infection. The proportion of seropositives seemed to increase with age, in agreement with findings in previous studies in other species. Genotyping of brain tissue by PCR was not successful what concerned $T$. gondii genomic DNA. This first report of Toxoplasma gondii infection in Norwegian red foxes from Finnmark County indicates that $T$. gondii is fairly common in red foxes from this area, and the high seroprevalence might be explained by widespread of the parasite in the diet of the foxes. This implies that the red fox is a host of significance in the maintaining of T. gondii in this northern region.

Published: 13 October 2010

doi:10.1186/1751-0147-52-S1-S12

Cite this article as: Andresen: A survey for Toxoplasma gondii in red fox

(Vulpes vulpes) from Finnmark County, Norway. Acta Veterinaria

Scandinavica 2010 52(Suppl 1):S12.

Norwegian School of Veterinary Science, Department of Food Safety and Infection Biology, Section of Arctic Veterinary Medicine, Stakkevollveien 23, NO-9010 Tromsø, Norway
Submit your next manuscript to BioMed Central and take full advantage of:

- Convenient online submission

- Thorough peer review

- No space constraints or color figure charges

- Immediate publication on acceptance

- Inclusion in PubMed, CAS, Scopus and Google Scholar

- Research which is freely available for redistribution

Submit your manuscript at www.biomedcentral.com/submit
C Biomed Central 